\title{
PENGARUH MINAT MEMBACA DAN PENGUASAAN KOSAKATA TERHADAP KETRAMPILAN BERBICARA BAHASA INGGRIS SISWA (SMK) DI KECAMATAN BASO, SUMATERA BARAT
}

\author{
Edri \\ Akademi Pariwisata Jakarta \\ Email: edri.humana@gmail.com
}

\begin{abstract}
Abstrak
Penelitian bertujuan untuk menganalisis dan menguji kebenaran hipotesis mengenai pengaruh minat membaca terhadap keterampilan berbicara bahasa Inggris. Hipotesis penelitian yang diuji meliputi: Terdapat pengaruh minat membaca secara bersama sama terhadap keterampilan berbicara Bahasa Inggris. Terdapat pengaruh minat membaca terhadap keterampilan berbicara Bahasa Inggris. Metode penelitian yang digunakan adalah metode survey dengan analisis regresi korelasi ganda. Populasi di dalam penelitian ini adalah siswa kelas X di SMKN $1 \mathrm{Kec}$ Baso, Sumatera Barat. Hasil penelitian menyimpulkan bahwa terdapat pengaruh yang signifikan minat membaca dan penguasaan kosa kata terhadap kemampuan berbicara Bahasa Inggris.
\end{abstract}

Kata Kunci: Minat Membaca, Ketrampilan Berbicara

\begin{abstract}
The research aims to analyze and discuss hypotheses regarding reading interest and word acquisition for the ability to speak English. The research hypothesis: Regarding interest in reading and mastery of shared words for English speaking skills. Related to interest in speaking in English, related mastering vocabulary words in English speaking skills grade. The research method used was a survey method with multiple regression analysis. The population of this research are students SMK Kec Baso Sumatera Barat Grade X. The results consider the fact that shows a significant interest in reading and vocabulary mastery in English speaking ability. This research summary is a positive publication of Interest in Reading and Vocabulary Mastery on the Capabilities of students.
\end{abstract}

Keywords: Reading Interest, Vocabulary of Master.

\section{PENDAHULUAN}

Bahasa adalah alat yang digunakan dalam berkomunikasi dalam kehidupan seharihari. Bahasa dipandang sebagai alat yang efektif untuk menciptakan peserta didik yang tangguh dan kompetitif, oleh karena itu dalam pembelajaran bahasa Inggris dikembangkan empat aspek keterampilan berbahasa diantaranya: (1) membaca, (2) menyimak, (3) berbicara dan (4) menulis.

Keterampilan berbicara amat penting dengan menguasai keterampilan berbicara, peserta didik akan mampu mengekspresikan pikiran dan perasaannya secara cerdas sesuai konteks dan situasi pada saat dia sedang berbicara,
Keterampilan berbicara juga akan mampu membentuk generasi masa depan yang kreatif sehingga mampu melahirkan tuturan atau ujaran yang komunikatif, jelas, runtut, dan mudah dipahami. Selain itu, keterampilan berbicara juga akan mampu melahirkan generasi masa depan yang kritis karena mereka memiliki kemampuan untuk mengekspresikan gagasan, pikiran, atau perasaan

Kepada orang lain secara runtut dan sistematis. Bahkan, keterampilan berbicara juga akan mampu melahirkan generasi masa depan yang berbudaya karena sudah terbiasa dan terlatih untuk berkomunikasi dengan pihak lain sesuai dengan konteks 
dan situasi tutur pada saat dia sedang berbicara.

Bygate mengatakan bahwa dalam berbicara seseorang harus mempunyai pengetahuan keterampilan perspektif motorik, dan keterampilan interaktif [1].

Kemampuan berpikir seseorang dalam mengekresikan gagasan-gagasan akan nampak disaat ia berbicara tetapi pada kenyataan tidak semua siswa memiliki kemampuan yang baik dalam berbicara, pada saat berbicara terkadang seorang anak belum memiliki kemampuan untuk menyelaskan dengan tepat apa yang ada dalam pikirannya dengan apa yang diucapkannya sehingga orang yang mendengar kurang memahami apa yang dibicarakannya. Keterampilan untuk menyesuaikan apa yang ada dalam pikiran itulah yang menjadikan anak bila diberi tugas oleh guru untuk berbicara di depan kelas mengalami kesulitan. Kesulitan itu berupa kesulitan dalam memilih kosa kata yang sesuai dengan tepat.

Dalam berbicara penguasaan kosa kata memegang peranan penting karena dengan penguasaan kosa kata yang baik kegiatan komunikasi dengan orang lain akan terjalin dengan baik sebagaimana dikatakan oleh Tarigan berpendapat bahwa kualitas keterampilan berbicara seseorang jelas tergantung kepada kuantitas dan kualitas kosa kata yang dimilikinya [2]. Selain faktor penguasaan kosa kata yang mempengaruhi keterampilan berbicara adalah minat membaca Minat membaca yang tinggi maka siswa akan banyak memperoleh berbagai konsep, pengetahuan dan informasi sehingga siswa akan trampil dalam berbicara sesuai dengan konteks, runtut dan jelas sehingga dapat dipahami oleh orang lain. Minat membaca yang tinggi akan mendorong dan menjadikan kegiatan membaca lebih bermakna dan berkualitas. Minat membaca yang rendah dan penguasaan kosa kata menjadi pemicu sehingga siswa memiliki kepercayaan diri untuk berbicara ketika guru memberikan tugas.

Secara umum minat dapat diartikan sebagai suatu kecenderungan yang menyebabkan seseorang berusaha untuk mencari ataupun mencoba aktivitasaktivitas dalam bidang tertentu. Minat juga diartikan sebagai sikap positif anak terhadap aspek-aspek lingkungan. Ada juga yang mengartikan minat sebagai kecenderungan yang tetap untuk memperhatikan dan menikmati suatu aktivitas disertai dengan rasa senang.

Membaca merupakan kegiatan menyembunyikan kata kata tersaji dalam bentuk teks. Menurut [3] membaca merupakan suatu kegiatan memberikan respon makna secara tepat terhadap lambang verbal yang tertulis. Pemahaman terjadi dari interaksi antara persepsi simbol- simbol grafts dan keterampilan bahasa serta pengetahuan pembaca. Dalam interaksi ini, pembaca berusaha manciptakan kembali makna sebagaimana makna yang ingin disampaikan oleh penulis dalam tulisannya.

Keterampilan berbahasa itu adalah lambang bunyi yang diucapan menempatkan berbicara sebagai kemampuan berbahasa yang utama. Menurut [4] memberikan lima konsep penting dalam berbicara, yaitu kemampuan berbicara adalah yang sangat penting untuk berkomunikasi, kemampuan berbicara adalah suatu proses yang kreatif, (3) kemampuan berbicara adalah hasil proses belajar, (4) kemampuan berbicara sebagai media untuk memperluas wawasan, dan (5) kemampuan berbicara dapat dikembangkan dengan berbagai topik. 
Keluhan tentang rendahnya keterampilan berbicara siswa terjadi di Sekolah Menengah Kejuruan (SMK) Negeri 1 Baso Kecamatan Baso Kab Agam Sumatera Barat sehingga mendorong peneliti dan tertarik untuk mengadakan penelitian guna menguji ada tidaknya pengaruh signifikan antar minat membaca dan penguasaan kosa kata terhadap keterampilan berbicara.

Berdasarkan uraian latar belakang di atas, maka dapat mengidentifikasi beberapa masalah yang berkaitan dengan minat membaca Bahasa Inggris, penguasaan kosa kata dan keterampilan berbicara, diantaranya (1) Apakah terdapat pengaruh minat membaca dan penguasaan kosakata secara bersama-sama terhadap keterampilan berbicara Bahasa Inggris Siswa di Sekolah Menengah Kejuruan (SMK) Negeri Kecamatan Baso?. (2) Apakah terdapat pengaruh minat membaca terhadap keterampilan berbicara Bahasa Inggris Siswa di Sekolah Menengah Kejuruan (SMK ) Negeri Kecamatan Baso?. (3). Apakah terdapat pengaruh penguasaan kosakata terhadap keterampilan berbicara Bahasa Inggris Siswa di Sekolah Menengah Kejuruan (SMK ) Negeri Kecamatan Baso?

\section{METODE}

Penelitian ini dilakukan di SMK Negeri Kecamatan Baso, Kabupaten Agam, penelitian dilakukan pada siswa kelas $\mathrm{X}$ berjumlahnya 40 orang siswa. yang diambil secara random. Metode penelitian yang digunakan ini adalah metode survey, kemudian data hasil survai dianalisi dengan menggunakan analisis regresi linier ganda.

Teknik pengumpulan data yang digunakan dalam penelitian ini adalah: 1. tes lisan berbentuk berpidato digunakan untuk mendapatkan data tentang keterampilan berbicara Untuk menghindari kesubjektifan, penilaian berpidato siswa dilakukan oleh dua orang yaitu peneliti, guru bahasa Inggris. Nilai akhir hasil berpidato siswa merupakan nilai rata- rata dari kedua penilai tersebut. 2. Angket atau kuesioner, teknik ini digunakan untuk mendapatkan data tentang minat membaca siswa yaitu dengan kuesioner skala sikap.

Dalam penelitian ini terdapat tiga variabel yaitu dua variabel bebas (Xi dan $\mathrm{X}_{2}$ ) dan satu variabel terikat (Y). Variabel bebas pertama adalah minat membaca (Xi) dan variabel bebas kedua adalah penguasaan kosakata $\left(\mathrm{X}_{2}\right)$. Sebagai variabel terikatnya adalah keterampilan berbicara (Y).

Berdasarkan sifat dan jenis hipotesis yaitu mencari pengaruh minat membaca terhadap keterampilan berbicara, pengaruh penguasaan kosakata terhadap keterampilan berbicara, dan pengaruh minat membaca dan penguasaan kosakata secara bersama-sama terhadap keterampilan berbicara.

Instrumen penelitian berupa angket minat membaca, penguasaan kosakata, dan tes lisan keterampilan berbicara semuanya dikembangkan penulis yang mengacu pada kisi-kisi atau indikator variabel.

Sebelum digunakan untuk mengambil data penelitian, instrumen penelitian yang berupa angket (minat membaca), tes (penguasaan kosakata), dan tes lisan (keterampilan berbicara) perlu diujicobakan untuk mengetahui tingkat validitas butir soal dan reliabilitasnya. 
Teknik Analisis Data, Analisis data dimaksudkan untuk menguji hipotesis yang telah diajukan.

\section{HASIL DAN PEMBAHASAN}

Berdasarkan data yang diperoleh dari sampel yang diujikan melalui deskripsi data statistik ditujukan untuk mengetahui data yang diperoleh dari hasil penelitian yang menggunakan aplikasi komputer program SPSS 16.0. Analisa deskripsi data bertujuan untuk mengetahui range dari data, mean, median, mode, standar deviasi, standar error of mean, minimun dan maximum, Deskripsi statistik dari perhitungan dan tes yang dilakukan oleh aplikasi komputer melalui program SPSS 16.0 .

\section{Analisis Data Minat Membaca $\left(\mathbf{X}_{1}\right)$}

Berdasarkan hasil instrumen minat membaca yang diberikan terhadap 40 Siswa diperoleh informasi dari hasil distribusi frekuensi data kelompok kelas interval, sebagai berikut: skor tertinggi adalah 73, skor terendah adalah 40, ratarata $(X)=51,80$ skor simpangan baku (s) $=8,645$, modus $(\mathrm{Mo}\}=54$ dan median $(\mathrm{Me})=51$. Dari hasil deskripsi data di atas dapat diartikan bahwa tingkat Kreativitas minat membaca Siswa termasuk Normal.

\section{Analisis Data Penguasaan Kosakata $\left(\mathbf{X}_{2}\right)$}

Berdasarkan hasil instrumen Penguasaan Kosakata yang diberikan terhadap 40 Siswa diperoleh informasi dari hasil distribusi frekuensi data kelompok kelas interval, skor Penguasaan Kosakata sebagai berikut: skor tertinggi adalah 82, skor terendah adalah 40 , rata-rata $(\mathrm{X})=$ 55,20 skor simpangan baku $(\mathrm{s})=10,376$, modus $(\mathrm{Mo})=48$, dan median $(\mathrm{Me})=54$. Dari hasil deskripsi data di atas dapat diartikan bahwa tingkat Penguasaan Kosa Kata termasuk Normal.

\section{Analisis Data Keterampilan Berbicara (Y)}

Berdasarkan hasil instrumen Keterampilan Berbicara yang diberikan terhadap 40 Siswa diperoleh informasi dari hasil distribusi frekuensi data kelompok kelas interval, skor Keterampilan Berbicara sebagai berikut: skor tertinggi adalah 90, skor terendah adalah 60 , rata-rata $(\mathrm{X})=$ 72,98 skor simpangan baku (s) $=7,444$ modus $(\mathrm{Mo})=68$ dan median $(\mathrm{Me})=71$. Dari hasil deskripsi data di atas dapat diartikan bahwa tingkat Keterampilan Berbicara termasuk Normal.

Disimpulkan bahwa data skor kemampuan berbicara siswa dalam penelitian ini memiliki sebaran yang cendrung normal.

\section{Analisis Pengujian Persyaratan}

Analisis pengujian persyaratan yang dilakukan dalam penelitian ini adaiah pengujian normalitas, multikolinearitas dan pengujian linearitas garis regresi partial antara variabel bebas dan variabel terikat.

\section{Pengujian Normalitas}

Pengujian persyaratan normalitas variabel terikat terhadap variabel bebas dilakukan dengan menggunakan uji KolmogorovSmirnov Test (Liliefors). Untuk hasilnya pada pengujian ini menggunakan hipotesis nol yang menyatakan adanya kesesuaian antara masing-masing data mentah yang berdistribusi normal terhadap hipotesis tanding dari data masing-masing yang tidak berdistribusi normal.

\section{Pengujian Hipotesis}

Tabel 1

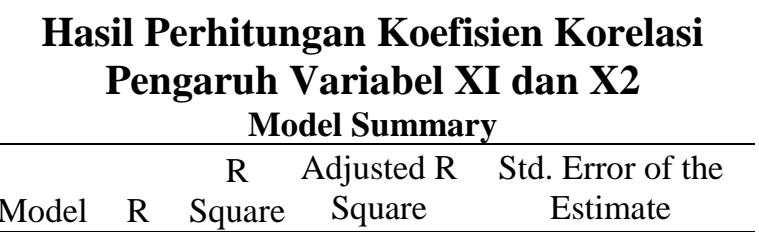




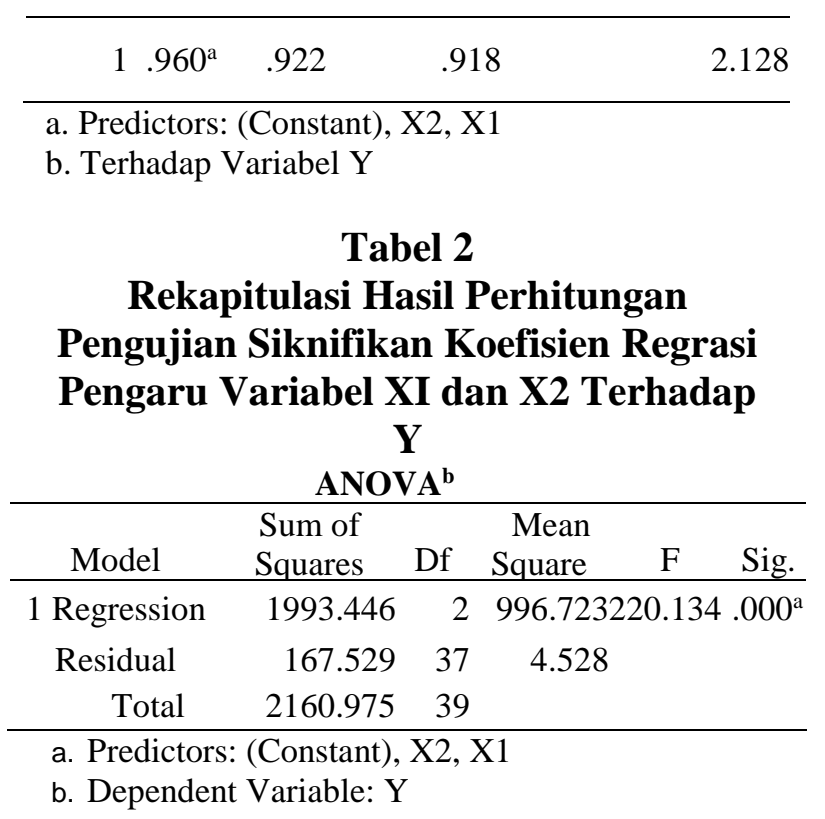

\section{Tabel 3}

Rekapitulasi Hasil Perhitungan

Persamaan Garis Regresi Pengaruh

Variabel XI dan X2 Terhadap Y

Coefficients $^{3}$

\begin{tabular}{|c|c|c|c|c|}
\hline \multirow[b]{2}{*}{ Model } & \multicolumn{2}{|c|}{$\begin{array}{l}\text { Unstandardized } \\
\text { Coefficients }\end{array}$} & \multirow{2}{*}{$\begin{array}{c}\text { Standardized } \\
\text { Coefficients } \\
\text { Beta } \\
\end{array}$} & \multirow[b]{2}{*}{ Sig. } \\
\hline & $\mathrm{B}$ & Std. Error & & \\
\hline 1 (Consta & 30.718 & 2.071 & 14.830 & .000 \\
\hline $\mathrm{X} 1$ & .501 & .079 & .5826 .375 & .00 \\
\hline $\mathrm{X} 2$ & .296 & .065 & .4124 .518 & .00 \\
\hline
\end{tabular}

a. Dependent Variable: Y

Pengaruh Minat Membaca (XI), dan Penguasaan Kosa Kata (X2) secara bersama - sama terhadap Keterampilan Berbicara Bahasa inggris

Dari tabel 1 diatas terlihat bahwa koefisien korelasi ganda pengaruh variabel bebas Minat Membaca (Xi) dan Penguasaan Kosa Kata $\left(\mathrm{X}_{2}\right)$ secara , dengan kata lain bahwa terdapat pengaruh yang signifikan bersama-sama terhadap kemampuan menulis kalimat efektif (Y) adalah sebesar 0,960 .

Dalam tabel 2 terlihat bahwa nilai sig = 0.000 dan Fhitung $=220,134$ sedangkan Ftabel 327 Karena nilai sig $<0,05$ dan
Fhitung > Ftabel maka $\mathrm{HO}$ ditolak dan Hi diterima yang berarti bahwa koefisien regresi tersebut signifikan. Berarti bahwa terdapat pegaruh signifikan dari variabel bebas Xi (Minat Membaca dan $\mathrm{X}_{2}$ (penguasaan Kosa Kata) secara bersamasama terhadap Y (kemampuan Berbicara bahasa Inggris)

Dari hasil pengujian korelasi maupun regresi tersebut maka bisa disimpulkan bahwa terdapat pengaruh Minat Membaca (X1 dan penguasaan Kosa kata (X2) secara bersama-sama terhadap kemampuan Berbicara bahasa Inggris (Y).

Pengaruh Minat Membaca (Xi) Terhadap Keterampilan Berbicara Bahasa Inggris (Y)

Untuk melihat pengaruh dari Xi terhadap Y maka perlu dibuatkan hipotesisnya.

Untuk membuktikan hipotesis tersebut adalah dengan memperhatikan nilai / bilangan yang tertera pada kolom $\mathrm{t}$ atau kolom sig untuk baris Minat Membaca (variabel Xi) pada tabel 3.

Dari tabel 3 terlihat bahwa nilai sig $=$ 0,000 dan nilai thitung $=6,375$ sedangkan $\mathrm{t}_{\mathrm{ta}}$ bei $=205$ karena nilai sig $<0,05$ dan thitung > ttabei maka Ho ditolak dan $\mathrm{H}$ ] diterima yang berarti terdapat pengaruh yang signifikan variabel bebas $\mathrm{Xi}$ (Minat Membaca) terhadap variabel terikat $\mathrm{Y}$ (kemampuan Berbicara bahasa Inggris)

Dari hasil pengujian korelasi, pengujian regresi maupun dengan melihat model garis tersebut maka bisa disimpulkan bahwa terdapat pengaruh yang signifikan variabel bebas $\mathrm{Xi}$ (Minat Membaca) terhadap variabel terikat $\mathrm{Y}$ (kemampuan Berbicara bahasa Inggris). 


\section{Pengaruh Penguasaan Kosa Kata (X2) Terhadap Keterampilan Berbicara Bahasa Inggris (Y)}

Dari pengujian hipotesis diperoleh nilai sig $=0,000$ dan thitung $=4,518$ sedangkan $\mathrm{t}_{\mathrm{ta}}$ bei $=205$ karena nilai sig $<0,05$ dan thitung > ttabei maka Ho ditolak dan $\mathrm{Hl}$ diterima yang berarti terdapat pengaruh yang signifikan dari variabel bebas $\mathrm{X} 2$ (penguasaan Kosa Kata) terhadap variabel terikat Y (kemampuan Berbicara bahasa Inggris).

Menurut teori yang ada, penguasaan tata bahasa adalah kemampuan yang dimiliki seseorang untuk menguasai aturan-aturan tentang bahasa itu sendiri. Secara operasional penguasaan tata bahasa diukur melalui tes tertulis dan dengan tes tersebut siswa-siswa dituntut untuk menyelesaikan soal-soal yang dihadapi, Dari uraian teoritis tersebut bisa diasumsikan bahwa semkin tinggi penguasaan Kosa Kata maka akan semakin tinggi kemampuan berbicara bahasa Inggris dengan benar.

Dari informasi kuantitatif dan teori tersebut maka peneliti berkesimpulan bahwa penguasaan tata bahasa mempunyai pengaruh yang positif dan signifikan terhadap kemampuan berbicara bahasa Inggris.

Penelitian ini dilakukan untuk mengetahui pengaruh tingkat Minat Membaca dan penguasaan Kosa Kata secara bersamasama terhadap keteramilan Berbicara bahasa Inggris.

\section{Pengaruh Minat Membaca dan penguasaan Kosa kata secara bersama- sama terhadap Keterampilan berbicara bahasa Inggris}

Dari deskripsi data diperoleh koefisien korelasi sebesar $=0,96$ dan koefisiendeterminasi sebesar $=0,922$ atau
92,2 \% setelah dilakukan pengujian dengan program SPSS 16.0 terbukti bahwa koefisien korelasi tersebut signifikan. Hal ini bearti bahwa terdapat pengaruh variabel bebas XI (Minat membaca) dan X2 (penguasaan Kosa Kata) secara bersamasama terhadap variabel terikat $\mathrm{Y}$ (kemampuan Berbicara bahasa Inggris).

Sedangkan dari analisa regresi diperoleh persamaan garis regresi $=\mathrm{Y}=$ $30,718+0,501 \mathrm{Xi}+0,296 \mathrm{Xj}$ nilai konstanta 307,8 menunjukan bahwa dengan Minat Membaca yang tinggi lebih mudah bagi siswa untuk meningkatkan kemampuan berbicara bahasa nggris.Sedangkan nilai koefesien regresi untuk XI dan X2 adalah sebesar 0,501 dan 0,296 menunjukan bahwa terdapat pengaruh positive variabel XI (Minat Membaca) dan X2 (penguasaan Kosa Kata) secara bersama-sama terhadap variabel terikat Y (kemampuan Berbicara bahasa Inggris). Angka koefisien regresi tersebut juga menunjukan bahwa setiap ada kenaikan satu nilai Minat Membaca maka akan terdapat kenaikan kemampuan Berbicara bahasa Inggris sebesar 0,501 dan setiap ada kenaikan satu nilai penguasaan Kosa Kata maka akan terdapat kenaikan kemampuan berbicara bahasa Inggris sebesar 0,296

Setelah diadakan pengujian linearitas garis regresi dengan menggunakan program SPSS 16.0, diperoleh bahwa garis regresi tersebut linear. Dari pengujian signifikansi koefisien regresi yang juga dilakukan dengan program SPSS 16.0 diperoleh bahwa koefisien regresi tersebut signifikan, yang berarti benar bahwa terdapat pengaruh yang positive variabel bebas XI (Minat Membaca) dan X2 (penguasaan Kosa Kata ) secar bersamasama terhadap variabel terikat $\mathrm{Y}$ (kemampuan Berbicara bahasa Inggris). 
Menurut teori bahwa bahasa adalah kemampuan seseorang untuk menguasai aiuran-aturan yang terdapat dalam bahasa itu sendiri. Aturan-aturan itu bisa berupa phonologi, morfologi dan lain sebagainya.

\section{SIMPULAN}

Berdasarkan hasil analisis penelitian dapat disimpulkan hal-hal sebagai berikut: (1) Hasil perhitungan rumus koefisien korelasi bahwa terdapat pengaruh positif Minat Membaca dan Penguasaan Kosa Kata bersama-sama terhadap Keterampilan Berbicara. (2) Hasil perhitungan rumus koefisien korelasi bahwa terdapat pengaruh positif Minat Membaca terhadap Keterampilan Berbicara. Variasi Keterampilan Berbicara dipengaruhi oleh Minat Membaca. (3) Makin berkualitas Penguasaan Kosa Kata, makin kuat Keterampilan Berbicara. Hal ini menunjukkan bahwa kualitas Penguasaan Kosa Kata akan semakin memperkuat Keterampilan Berbicara siswa.

\section{DAFTAR PUSTAKA}

[1] Bygate, Martin. Speaking. Great Clarendon Street. Oxford OX26D: Oxford University, 1977.

[2] Hendry Guntur Tarigan. Berbicara Sebagai Suatu keterampilan Berbahasa. Bandung: Angkasa, 2008.

[3] Harris, A.J., \& E.R Sipay. How to Increase Reading Ability. New York: Longman, 1980.

[4] Douglas Brown. Teaching by Principles. Califomia: San Francisco State University, 2000.

[5] Moleong, J. Lexy. Metode Penelitian Kualitatif. Bandung: PT. Remajr Rosdakarya, 2006. 